\title{
EXAMINATIONS IN SANITARY SCIENCE FOR LOCAL SURVEYORS AND INSPECTORS OF NUISANCES.
}

\author{
BOARD OF EXAMINERS.
}

Ctyairnar.

Capt. Douglas GaLton, R.E., C.B., D.C.L., F.r.s.

H. C. BantLetT, PII.D., F.C.s.

Prof. W. H. Corfield, M.A. LOND, M.D. oxon.

Prof. F: S. B. F. de ChadMunt, M.D., F.R.s.

Rogers Field, B.A., M. MNST. c.E.

W. H. Micilael, Q.c., F.c.s.

Prof. H. Robinson, M.Inst. c.e.

M. Ogle Tarbotton, M.inst. c.E., F.G.S.

ERNest TURner, F.R.I.B.A.

Megistrax.

G. J. Srarons, F.R.s.

THE great and increasing importance of the duties devolving upon Local Surveyors and Inspectors of Nuisances in connection with the various Acts relating to Public Health, the Sale of Food and Drugs Act, \&c., has led the Council of the Sanitary Institute of Great Britain to establish Voluntary Examinations, to appoint a Board of Examiners, and to grant Certificates of Competency to Local Surveyors and Inspectors of Nuisances.

Visitors duly appointed by the Local Government Board and various bodies connected with the practical application of sanitary science are invited to be present at the Examinations.

The Examinations, which are arranged in two grades, are intended to enable Local Surveyors and Inspectors of Nuisances, or persons desirous of becoming such, or of obtaining the Certificate of the Institute, to prove their competency in the subjects of Examination. Successful Canclidates will be placed on the Register of persons so certificated ; this Register will be kept at the Offices of the Institute, and a copy will be forwarded to Local Boards and Sunitary Authorities on application.

Each Examination occupies a portion of two days. On the first day the Examination of surveyors occupies four hours-viz., from 2 till 4, and from 6 till 8 p.m., and consists of written papers only. Inspectors of Nuisances have two bours' written examination on the first day-viz., fiom 4 till 6 p.m. On the second day the Examination, for both classes, commences at $1 \mathrm{l}$ a.m., and is vivâ voce, 
with one or more questions to be answered in writing, if deemed necessary. A Certificate of competency, signed by the examiners, is granted to successful Candidates, entitling them to be designated as "Certificated by the Sanitary Institute of Great Britain."

As Rural Sanitary Authorities are able, under the Public Health Act, 1875, to obtain almost all the powers of Urban Sanitary Authorities, it is not considered advisable to make any distinction in the examination of the two classes of Surveyors.

As one person may, under the Public Health Act, 1875, be both Local Surveyor and Inspector of Nuisances, Candidates wishing to obtain the double qualification may enter for both Examinations on the same occasion.

Candidates are required to furnish to the Board of Examiners satisfactory testimonials as to personal character, and to give two weeks' notice to the Registrar previous to presenting themselves for Examination, stating whether they wish to be examined as Surveyors, as Inspectors of Nuisances, or as both. The fee for Examination must be paid to the Secretary, by Post-Office order or otherwise, at least six days before the day of Examination. On the receipt of the fee, a ticket will be forwarded admitting to the Examination.

The fees payable for the Examinations are as follows:-

For Surveyors . . . . £5 5s.

For Inspectors of Nuisances . . $£ 22 \mathrm{~s}$.

Unsuccessful Candidates are allowed to present thenselves a second time for one fee.

Examinations during the year 1882 are appointed to be held at the Rooms of the Institute :-

On Thursday and Friday, November 2nd and 3rd, 1882.

On Thursday and Friday, June 7th and 8th, 1883.

Forms to be filled up by Candidates previous to Examination will be supplied on application to the Secretary, 9, Conduit Street, W.

\section{SYLLABUS Of SUBJECTS for EXAMINATION.}

\section{FOR LOCAL SURVEYORS.}

LAWS AND BrE-LaWs-A thorough knowledge of the Acts affecting Sanitary Authorities, as far as they relate to the duties of Local Surveyors; also, of the Model Bye-Laws issued by the Local Government Board.

Sewdrage and Drasnage-The Sanitary principles which should be observed in the preparation of schemes for, and the construction of, Sewerage works: the ventilation and flushing of sewers and drains; the internal drainage and other Sanitary arrangements of houses, privies, water-closets, dry-closets, and the removal of refuse; the Sanitary details of Builders' and Plumbers' work. 